\title{
Ancestral Caddo Ceramic Vessels from the Wright Plantation (41RR7) and Rowland Clark (41RR77) Sites in the Harris Collection at the National Museum of Natural History, Smithsonian Institution
}

Timothy K. Perttula Heritage Research Center, Stephen F. Austin State University

Follow this and additional works at: https://scholarworks.sfasu.edu/ita

Part of the American Material Culture Commons, Archaeological Anthropology Commons, Environmental Studies Commons, Other American Studies Commons, Other Arts and Humanities Commons, Other History of Art, Architecture, and Archaeology Commons, and the United States History Commons

Tell us how this article helped you.

This Article is brought to you for free and open access by the Center for Regional Heritage Research at SFA ScholarWorks. It has been accepted for inclusion in Index of Texas Archaeology: Open Access Gray Literature from the Lone Star State by an authorized editor of SFA ScholarWorks. For more information, please contact cdsscholarworks@sfasu.edu. 


\section{Ancestral Caddo Ceramic Vessels from the Wright Plantation (41RR7) and Rowland Clark (41RR77) Sites in the Harris Collection at the National Museum of Natural History, Smithsonian Institution \\ Creative Commons License \\ (c) (1) \& 8}

This work is licensed under a Creative Commons Attribution-NonCommercial 4.0 International License 


\title{
Ancestral Caddo Ceramic Vessels from the Wright Plantation (41RR7) and Rowland Clark (41RR77) Sites in the Harris Collection at the National Museum of Natural History, Smithsonian Institution
}

\author{
Timothy K. Perttula
}

\begin{abstract}
Introduction
The collection of R. King Harris at the National Museum of Natural History (NMNH) at the Smithsonian Institution has ancestral Caddo ceramic vessels from the Wright Plantation (41RR7) and Rowland Clark (41RR77) sites along the Red River in East Texas (Figure 1). Other than the site provenience and the burial number of two of the vessels at the Rowland Clark site, there is no more detailed documentation available on when or where within the sites that Harris obtained the ceramic vessels. Nevertheless, it is important as part of the broader study of the history of Caddo ceramic vessel forms and decorative motifs to put these vessels on record.
\end{abstract}

\section{Wright Plantation Vessel}

The Wright Plantation site is a multiple mound center on the Red River, about $1 \mathrm{~km}$ north of the Fasken site (41RR14), another multiple mound center (Prikryl 2008), and $7 \mathrm{~km}$ upstream from the Sam Kaufman site (41RR16), a very large village with two constructed mounds and several discrete cemeteries (Perttula 2008). The site has both Mounds Prairie and McCurtain phase occupations at the site, and at least one of the mounds ("the low sandy mound" in R. King Harris notes) at Wright Plantation appears to have been constructed and used as a burial mound during the McCurtain phase. During the 1930s, the landowner, George Wright, recovered many ceramic vessels from this mound (Mound B), and this collection is now in the holdings of the University of Oklahoma.

The one vessel from the Wright Plantation site is a large shell-tempered and red-slipped Avery Engraved compound bowl (Figure 2). Such vessels are present in McCurtain phase contexts in this stretch of the Red River (see Perttula 2008:Figure 57c-d), most likely from post-A.D. 1500 contexts. Site records on the Texas Historic Sites Atlas indicate that a Hudson Engraved vessel, also dating to late McCurtain phase times, came from the "low sandy mound" along with a turquoise pendant.

\section{Rowland Clark Site Vessels}

R. King Harris referred to this site as owned by John Dews at the time he collected several Caddo vessels from a Burial 2. John Dews was listed as the site owner on the 1982 site form for the Rowland Clark site (41RR77).

Perino (1994) excavated ancestral Caddo burials from two cemeteries at the site, the first (with burials 1-21) dating to the early McCurtain phase (ca. A.D. 1300-1500), and the remainder (burials 22-39) dating to the late McCurtain phase (ca. A.D. 1550-1700). R. King Harris recovered four ceramic vessels from what he labeled as Burial 2 at the John Dews site. Unlike the burials excavated by Perino (1994), the Burial 2 ceramic vessels date to ca. A.D. 1000-1200 (in Early Caddo period times), based on the Spiro Engraved bottle from the burial (Figure 3). The other three vessels associated with the Spiro Engraved bottle include a plain bowl with lip tabs (Figure 4) and two plain carinated bowls (Figures 5-6). 


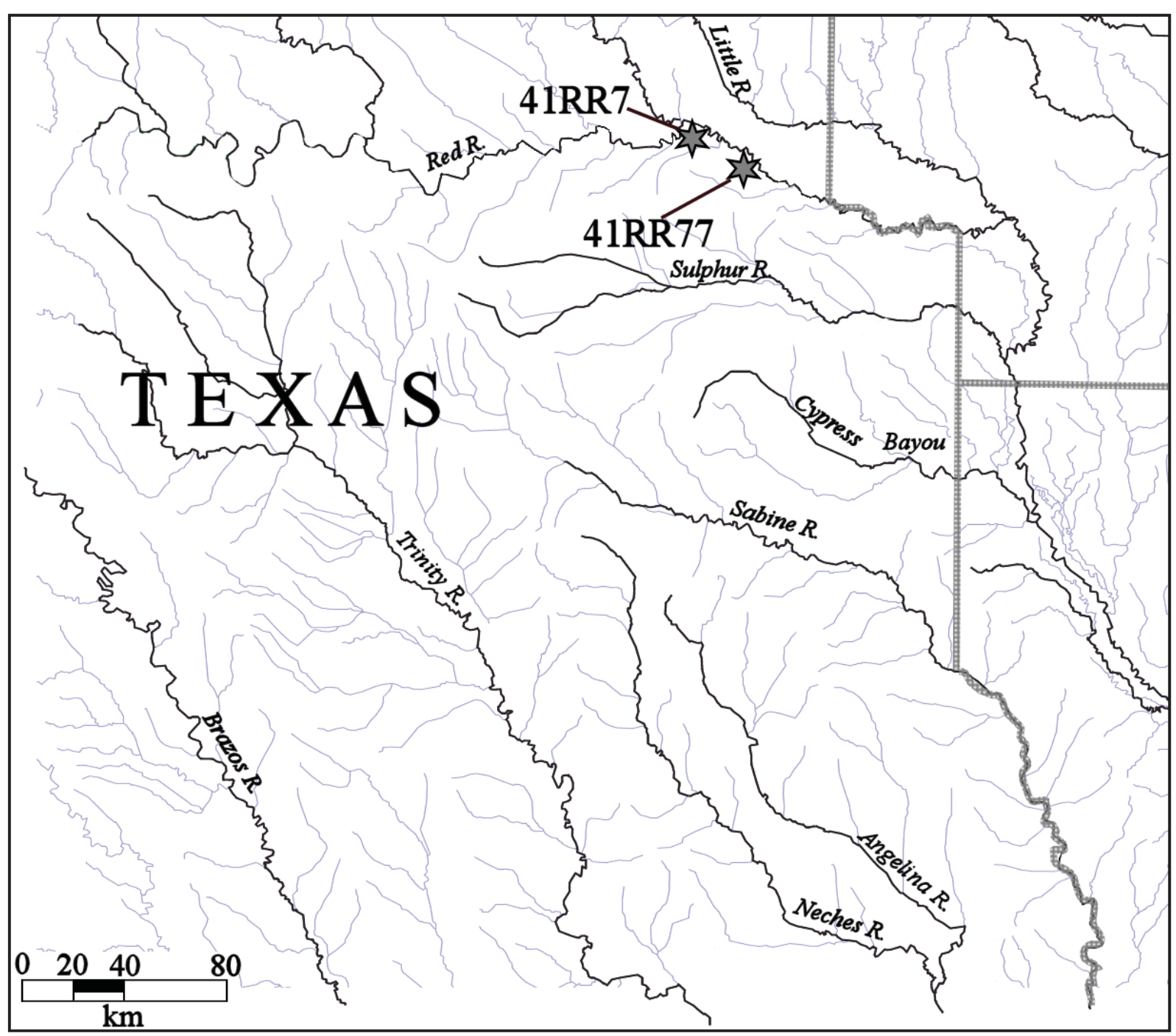

Figure 1. The locations of the Wright Plantation (41RR7) and Rowland Clark (41RR7) sites in East Texas.

\section{Summary and Conclusions}

Among the many ancestral Caddo ceramic vessels in the R. King Harris collection at the NMNH from Red River County, Texas, five vessels can be identified from the available records and notes from the Wright Plantation (41RR7) and Rowland Clark (41RR77) sites. The one vessel from the Wright Plantation site is a late McCurtain phase (ca. A.D. 1500-1700) red-slipped Avery Engraved compound bowl, likely obtained from a low sandy mound at the site. The four ceramic vessels from a burial at the Rowland Clark site date to Early Caddo period times (ca. A.D. 1000-1200), rather than to burials excavated by Perino (1994) at the site that date to early and late McCurtain phase contexts.

\section{Acknowledgments}

Thanks to the staff at the National Museum of Natural History (NMNH) for access to the King Harris collections, and also to Robert Cast and Bobby Gonzalez, then working in the Historic Preservation Program at the Caddo Nation of Oklahoma, who arranged the documentation visit to the NMNH. Bo Nelson took the photographs in this article, and Mark Walters assisted with the 2005 vessel documentation. Lance Trask prepared Figure 1. 


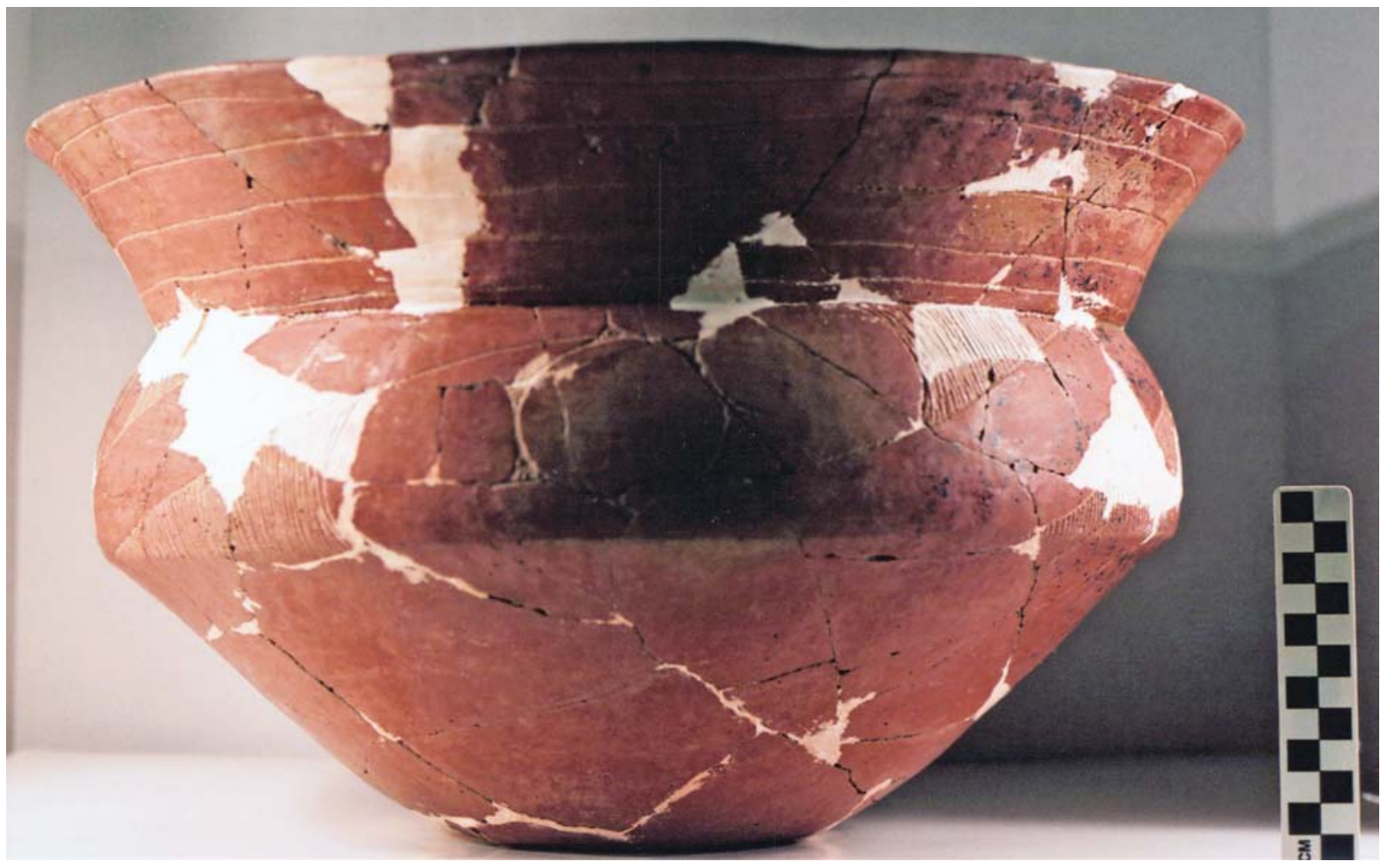

Figure 2. Avery Engraved compound bowl from the Wright Plantation site (A513396).
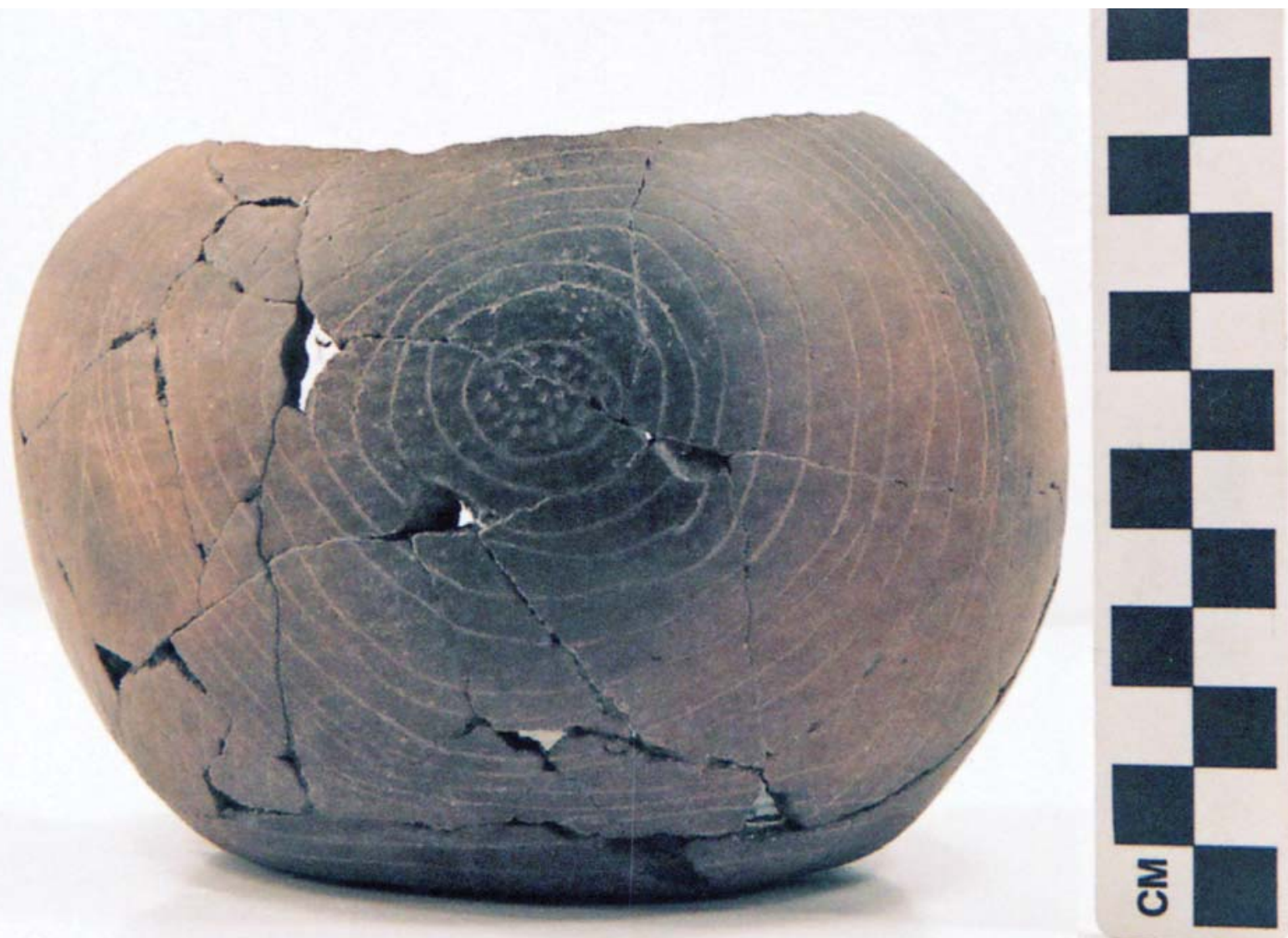

Figure 3. Spiro Engraved bottle from the Rowland Clark site (A513531). 


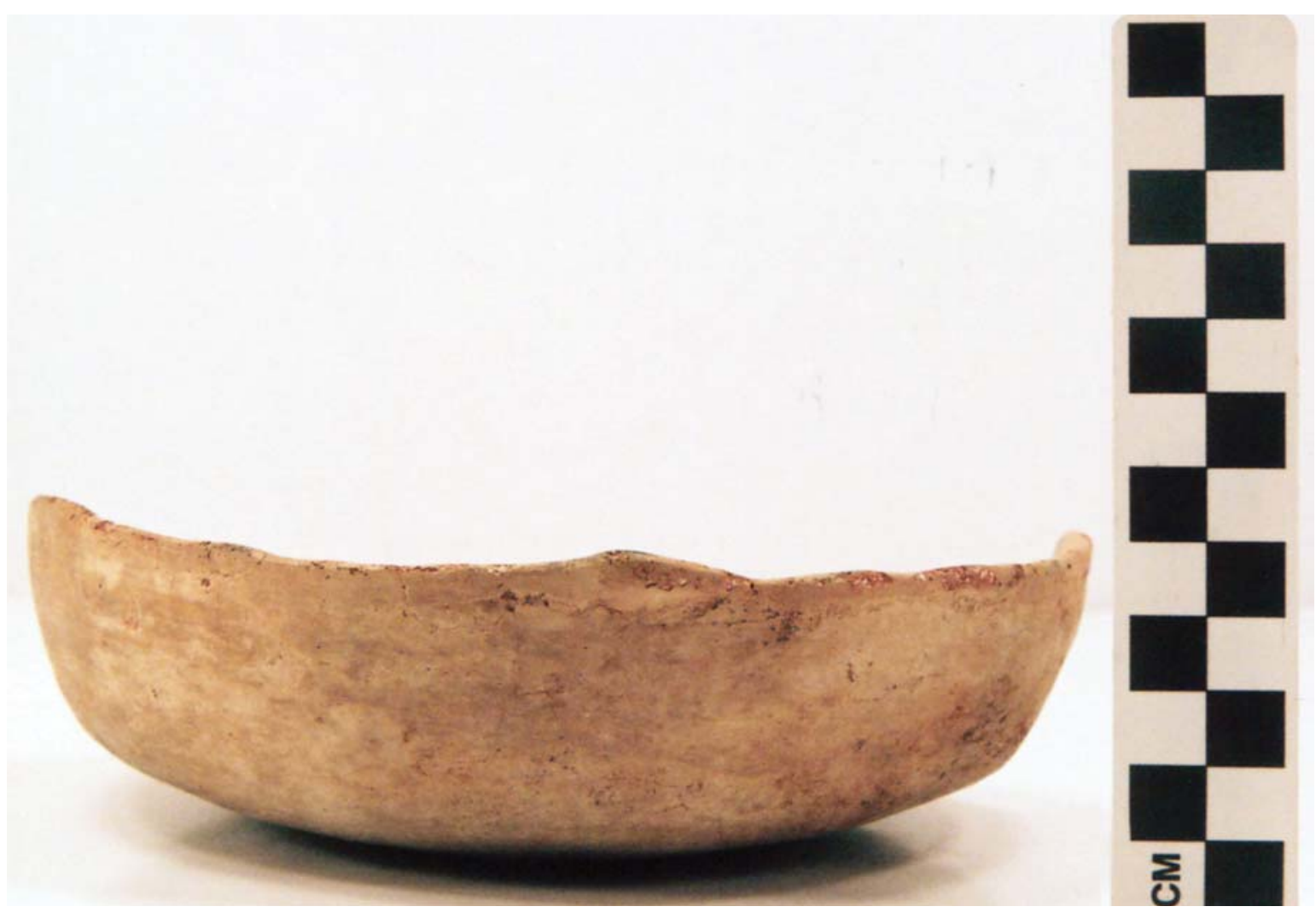

Figure 4. Plain bowl with lip tabs from the Rowland Clark site (A513533).
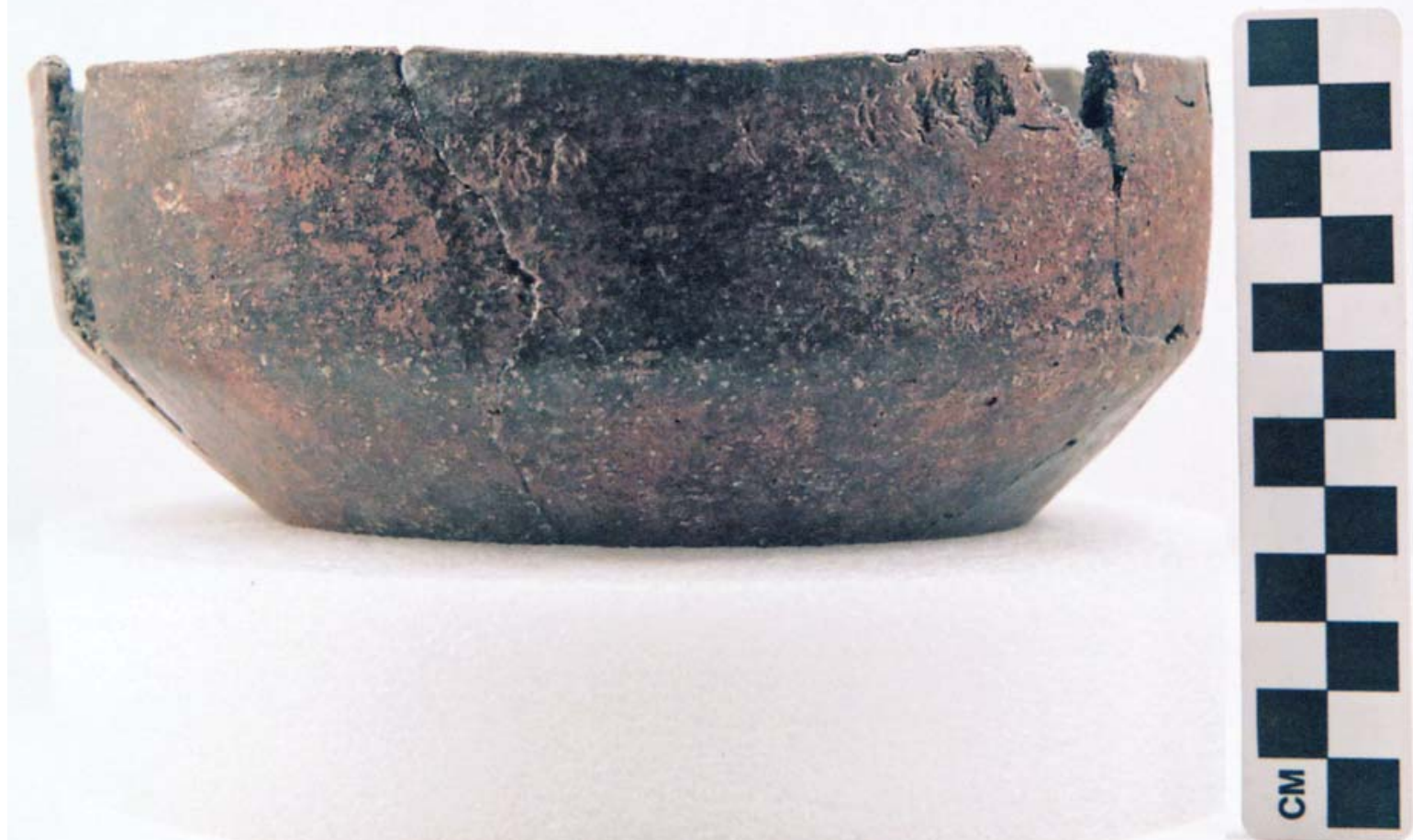

Figure 5. Plain carinated bowl from the Rowland Clark site (A513534). 


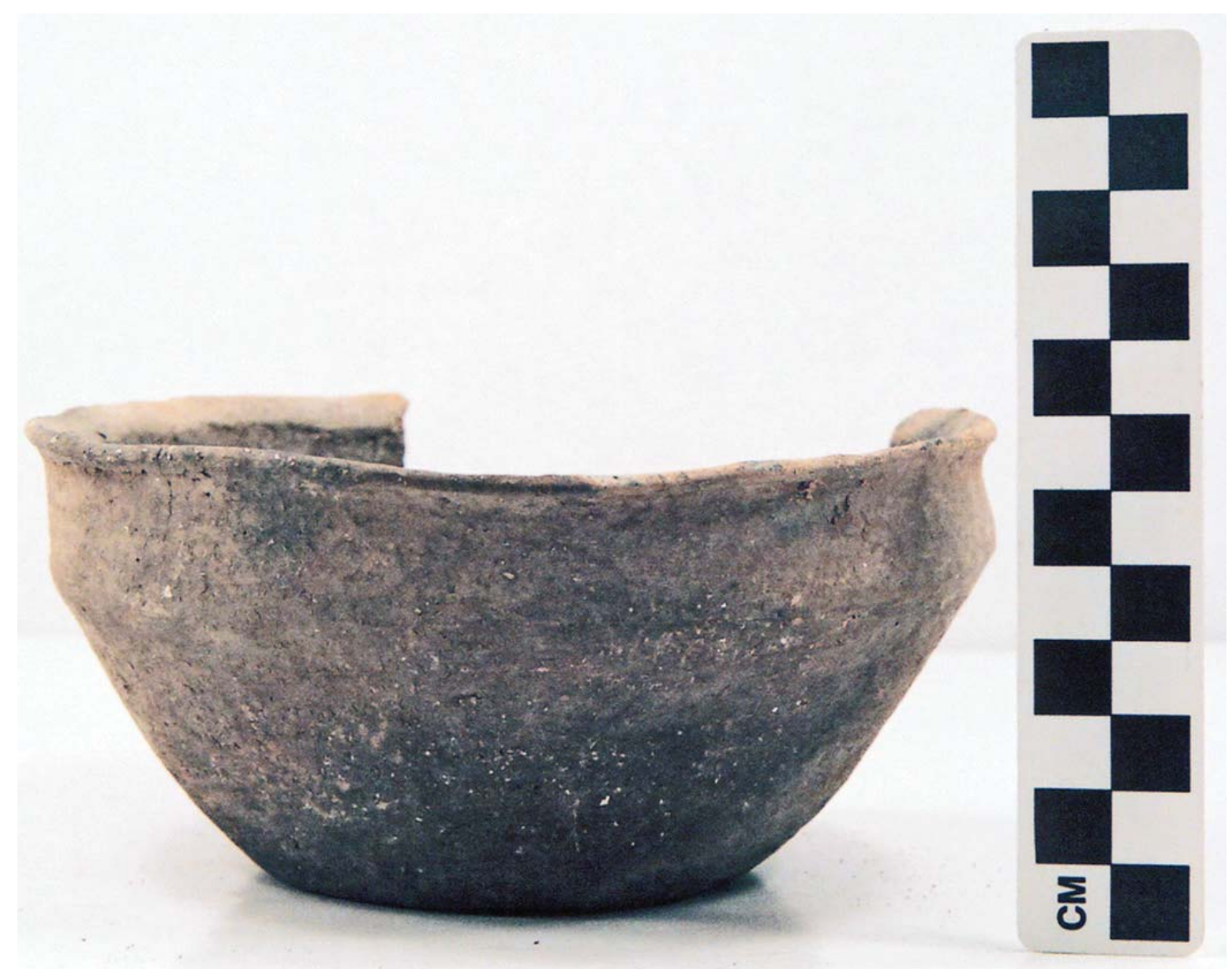

Figure 6. Second plain carinated bowl from the Rowland Clark site (A513532).

\section{References Cited}

Perino, G.

1994 Archaeological Research at the Rowland Clark Site (41RR77), Red River County, Texas. Journal of Northeast Texas Archaeology 4:3-42.

Perttula, T. K.

2008 The Archeology of the Roitsch Site (41RR16), an Early to Historic Caddo Period Village on the Red River in Northeast Texas. In Collected Papers from Past Texas Archeological Society Summer Field Schools, edited by T. K. Perttula, pp. 313-628. Special Publication No. 5. Texas Archeological Society, San Antonio.

Prikryl, D. J.

2008 The 1991 and 1992 Texas Archeological Society Field School Excavations at the Fasken Site (41RR14), Red River County, Texas. In Collected Papers from Past Texas Archeological Society Summer Field Schools, edited by T. K. Perttula, pp. 125-171. Special Publication No. 5. Texas Archeological Society, San Antonio. 